BIORHEOLOGY, 28; 353, 1991

$0006-355 X / 91 \$ 3.00+.00$ Printed in the USA.

Copyright (c) 1991 Pergamon Press plc. All rights reserved.

\title{
CONTENTS OF CLINICAL HEMORHEOLOGY, VOLUME 10, NUMBER 5
}

VOLUME 10, NUMBER 5

1990

S. Ikemoto, J. Yamamoto,

T. Yokose and Y. Isogai

A.M. Ehrly

V. Lipovac, M. Gavella, S. Crnek and $Z$. Rubinjoni

O.K. Başkurt, E. Levi, S.O. Andaç and $\mathrm{S}$. Çağlayan

D. Norcliffe and M.J. Brown

H. Kollegger, W. Oder, K. Zeiler, Ch. Baumgartner, C. Lind, B. Oder, Ch. Sagmeister and L. Deecke

Tze-Wen Chung and E.A. O'Rear

K. Ohta, F. Gotoh, M. Tomita, N. Tanahashi, M. Kobari, T. Shinohara, Y. Terayama, B. Mihara and M. Nara

E. Ernst, M. Schroeder, T. Saradeth, and $\mathrm{H}$. Bergmann

J. Stuart, P.C.W. Stone, G.B. Nash and J.C. Ellory

A. Craveri, G. Tornaghi, L. Paganardi, R. Ranieri and L. Giavardi

P.J. Kent, G. Williams and R.C. Kester

T. Khodabandehlou and C. Le Devehat

L. Judkiewicz, R. Ciszewski and $G$. Bartosz

\section{CONTENTS}

Conference Communication

Proceedings of the Seventh International

Congress of Biorheology, Nancy, France,

18-23 June 1989

Part IIa

Symposium: Hemorheology and

Cardiovascular Diseases

463 Hemorheological abnormalities in diabetics with cardiovascular disease

Non-Conference Communications

Papers

473 Some marginal notes on erythrocyte aggregation

477 Erythrocyte sialic acid and filterability in type 2 diabetic patients

485 Effect of sulfur dioxide inhalation on erythrocyte deformability

491 Haemorheological investigations in the early indentification of hypertension in pregnancy

499 Viscoelasticity of whole blood as a function of age, gender, cigarette smoking and intake of oral contraceptives

505 Assessing erythrocyte filterability with $3 \mu \mathrm{m}$ pore size polycarbonate membranes at constant cell flux

515 Hypertonic glycerol solution improves erythrocyte hyperaggregability in occlusive cerebrovascular disease

525 Analytical and physiological variations of some hemorheological and hematological blood tests

535 Effect of piracetam on $\mathrm{Ca}^{2+}$-induced $\mathrm{K}+$ efflux from sickle cells

541 Weight loss does not affect the hemorheological and fibrinolytic changes in obesity

547 Autotransfusion - The effects of cell salvage on the filterability of autotransfused red cell

Brief Communciation

557 Role of albumin and fibrinogen on red cell aggregation-disaggregation in diabetes mellitus Letter to the Editors-in-Chief

561 Effect of hematocrit on the erythrocyte susceptibility to centrifugal packing: Authors' reply

565 Announcement

567 Contents of Biorheology Volume 27, Number 2

I Software Survey Section 